\title{
A NEW SPECIES OF STREPTOCARPUS (GESNERIACEAE) FROM THE PONDOLAND COAST, SOUTH AFRICA
}

\author{
D. U. BELLSTEDT* \& T. J. EDWARDS $\dagger$
}

\begin{abstract}
The new species Streptocarpus lilliputana (Gesneriaceae), collected on the Pondoland coast, South Africa, is described. Although its alliances are not obvious in terms of corolla morphology and rosulate habit, it approaches $S$. gardenii and its allies. The pollen and stigma of $S$. lilliputana differ markedly from the stenopalynous grains and bilobed stigmas of the other South African rosulate species. Streptocarpus lilliputana is exceedingly rare and is a further endemic from the Pondoland centre.
\end{abstract}

Keywords. Gesneriaceae, new species, South Africa, Streptocarpus lilliputana.

\section{INTRODUCTION}

Evolution within Streptocarpus Lindl. seems to have been driven by geographic isolation and pollinator specialization, and the type subgenus is virtually devoid of fertility barriers (Hilliard \& Burtt, 1971; Weigend \& Edwards, 1994a). Thus, for species to maintain their integrity, prezygotic isolating mechanisms must be operating. The genus produces tiny seeds in copious amounts, and consequently populations have the potential to grow rapidly. However, Streptocarpus species are also susceptible to population collapses during drought episodes, such as those that occurred during Pleistocene glacial cycles, and these form evolutionary bottlenecks that drive population divergence. Such climatic cycles also introduce a dynamic in terms of forest cohesion. During warm wet cycles, forest patches expand and allow wide dispersal. Cool dry cycles are associated with forest shrinkage and fragmentation; these provide the impetus for allopatric speciation. The isolated patches of forest occurring along the Pondoland coast constitute refugia and form focal points for allopatric speciation of forest taxa. During dry cycles the patches are surrounded by extensive grasslands, which have experienced inverse cycles of shrinkage and expansion in relation to the forest patches. The grasslands are prone to fire, which during dry cycles also contributes to forest shrinkage. The steep river gorges provide a barrier for fire and appear to have been an ideal habitat for the evolution of endemic species and local ecotypes (Van Wyk, 1990; Matolweni et al., 2000; Van Wyk \& Smith, 2001).

\footnotetext{
* Department of Biochemistry, University of Stellenbosch, Private Bag X1, Matieland 7602, South Africa.

$\uparrow$ School of Botany and Zoology, University of Natal, Private Bag X01, Scottsville 3209, South Africa.
} 
An overview of Streptocarpus reveals a number of South African east coast endemics that are threatened to varying degrees: S. modestus L.L. Britten, $S$. trabeculatus Hilliard, S. formosus (Hilliard \& B.L. Burtt) T.J. Edwards, S. porphyrostachys Hilliard and S. kentaniensis L.L. Britten \& Story. In this study, a new endemic species, very localized and threatened in places, is described from the region and its possible affinities are outlined.

Streptocarpus lilliputana D.U. Bellstedt \& T.J. Edwards, sp. nov. Fig. 1.

Similis Streptocarpo gardenii Hook.f. sed regulatim minor, petiolodis radicatis, corolla mediodeflexa, polline globoso et non-perforato.

Type: South Africa, Eastern Cape, Lupatana River Gorge, Bellstedt 145 (holo. NU, iso. E).

Rosulate perennial, rhizome poorly developed. Leaves oblong, 50-90 × 15-20mm, sparsely strigose, dark green with distinct sheen above, light green below; midvein light purple; margin crenate; base decurrent; petiolode to $12 \times 2.5 \mathrm{~mm}$, red-brown, often with roots. Inflorescences 1 or 2 arising at top of petiolode, 1(2)-flowered; peduncle $25-30 \mathrm{~mm}$ long (the peduncle in Fig. 1 is somewhat too long), reddish brown to green; bracts $1-2$, spathulate, $0.5-3 \times 0.5-1 \mathrm{~mm}$; pedicel $8-23 \mathrm{~mm}$ long. Sepals linear, 5-6 $\times 1 \mathrm{~mm}$, greenish brown, strigose. Corolla c.50mm long, strigose outside, often with a median line of papillae on corolla floor, pale to medium violet, floor of tube usually dominated by 7 broad deep-violet stripes almost confluent in tube; tube 38-40mm long, curved downwards, narrowly cylindric in basal two-thirds $(25-30 \times 4 \mathrm{~mm})$, abruptly widening to $8 \mathrm{~mm}$ in distal third; mouth $11-12 \mathrm{~mm}$ across, dorsiventrally compressed, roof strigose; lower lip $15 \mathrm{~mm}$ long, with faint transverse lamellae, white with three violet stripes, lobes pale violet, oblong, $10 \times 6-7 \mathrm{~mm}$; upper lip $11 \mathrm{~mm}$ long, lobes oblong, $10 \times 6-7 \mathrm{~mm}$. Stamens arising in distal third of corolla; filaments c. $10 \mathrm{~mm}$ long, slightly twisted, pale violet, glabrous; anther lobes c. $2 \times 1 \mathrm{~mm}$ joined apically by a delicate ligature; lateral staminodes capitate, $3.2 \times 0.5 \mathrm{~mm}$, minute posterior staminode sometimes present. Ovary $15-18 \mathrm{~mm}$ long, densely strigose; style 20-23mm long, abruptly recurved at apex, sparsely strigose, flattened; stigma broadly clavate and cavitate, with conspicuous stylar canal. Capsule c.55-80 × 2.0-2.5mm. (Figs 1, 2)

Distribution and ecology. Known only from the forested river gorges of the Lupatana and the Mkozi Rivers. Plants grow in deep shade in sparse colonies on rock seepages.

Phenology. Flowers from November to February. Immature fruits seen in late January.

Etymology. The specific epithet lilliputana is a combination of lilliputian, meaning dwarf, and Lupatana River, the type locality.

The flowers of S. lilliputana are superficially similar to those of $S$. modestus, which occurs sympatrically, although no evidence of hybridization was found. Other 


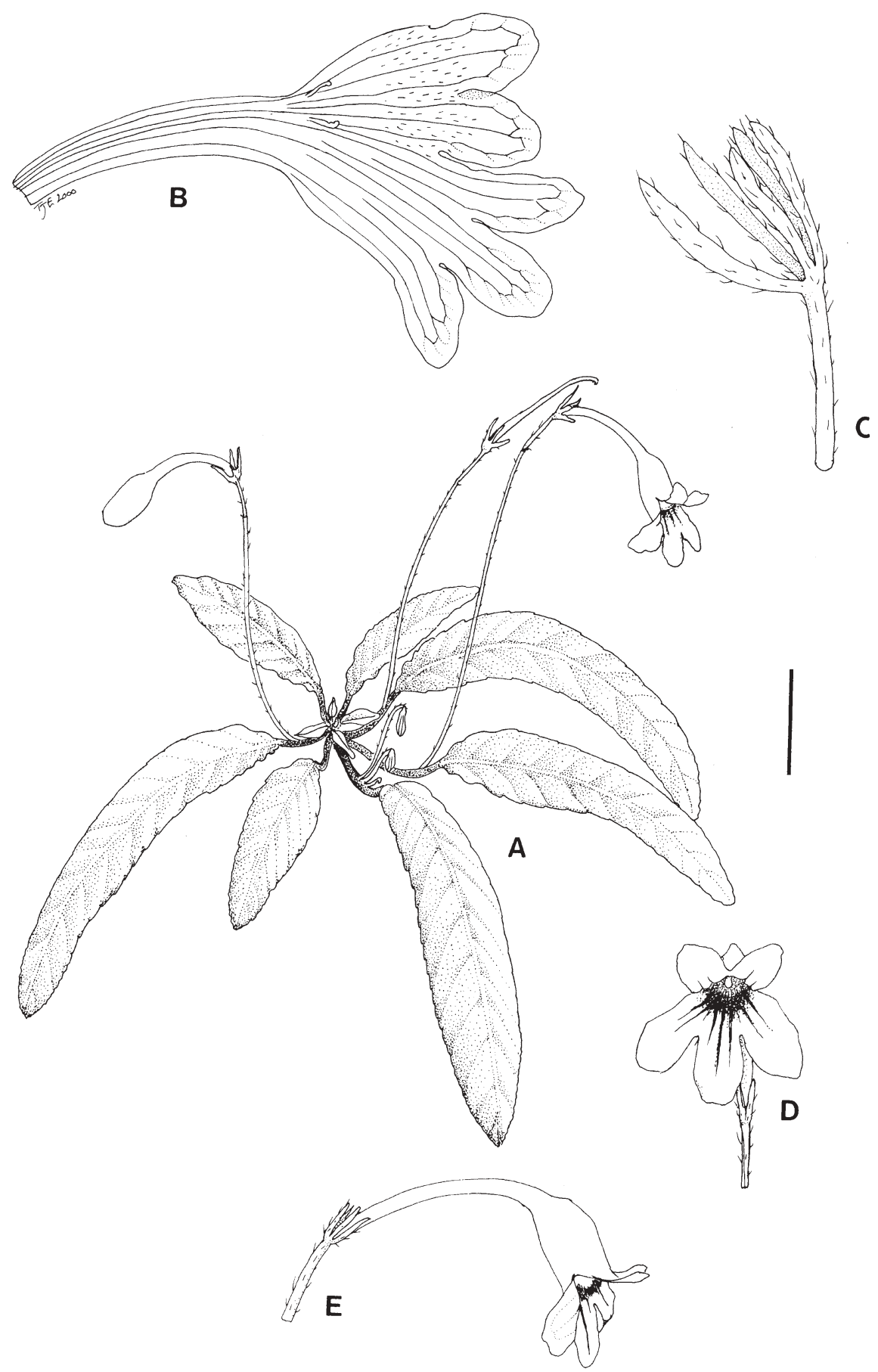

FIG. 1. Streptocarpus lilliputana (Bellstedt 145). A, flowering plant (scale bar $=25 \mathrm{~mm}$ ); B, corolla dissection (scale bar $=10 \mathrm{~mm}$ ); $C$, calyx $($ scale bar $=4 \mathrm{~mm}$ ); $\mathrm{D}$, corolla, frontal view (scale bar $=15 \mathrm{~mm})$; E, corolla, lateral view (scale bar $=15 \mathrm{~mm})$. Drawn by T.J. Edwards. 

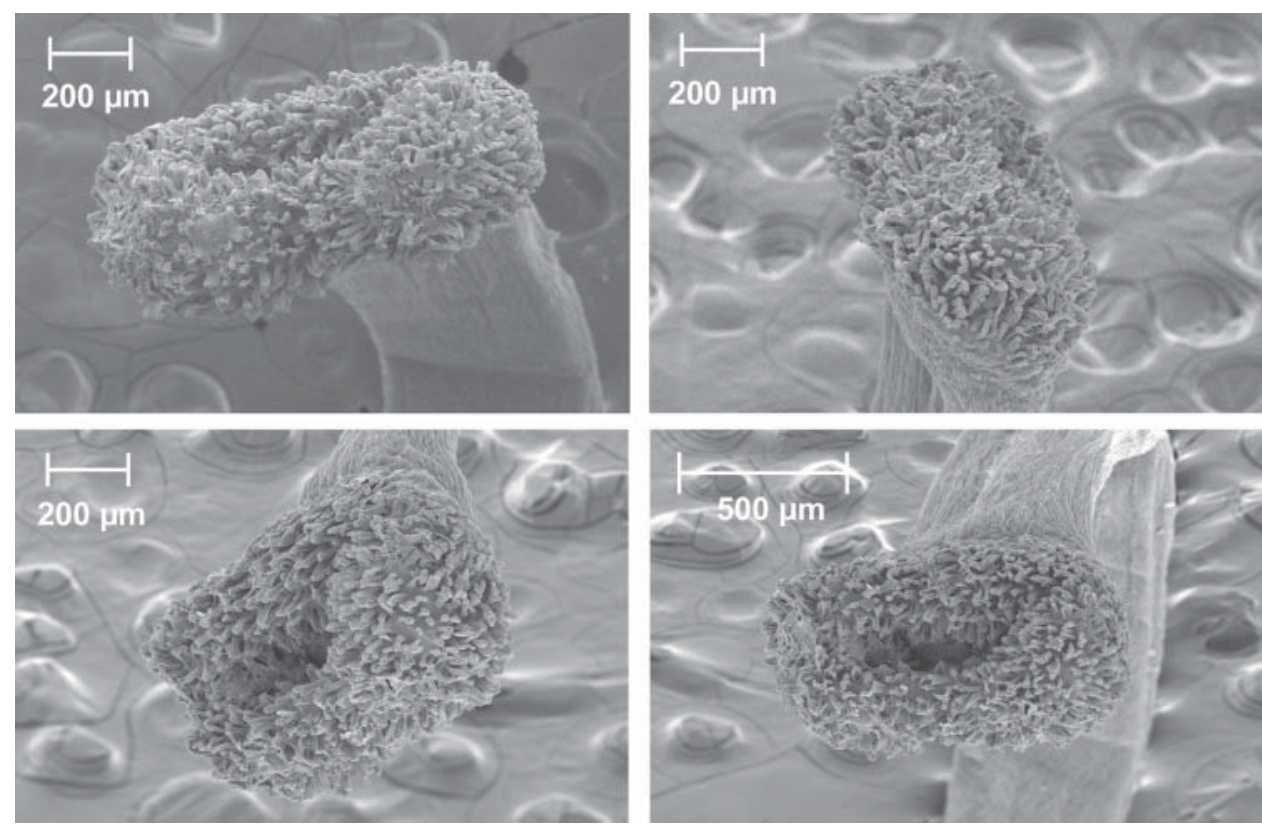

FIG. 2. Stigma of Streptocarpus lilliputana

(Bellstedt 145) under scanning electron microscopy.

Streptocarpus species that occur in the vicinity include $S$. haygarthii N.E. Br. ex C.B. Clarke and $S$. porphyrostachys, but these are not rosulate species as $S$. lilliputana is. The slight dorsiventral compression of the mouth of the corolla and the neatly ordered rosette of leaves with crenate margins and distinct petiolodes are reminiscent of $S$. gardenii, but the closest locality at which the latter occurs is at Mnyolo, approximately $100 \mathrm{~km}$ inland and at considerably higher elevation. The small, sparsely pubescent leaves with a distinct sheen, the deflexed arcuate corolla tube, the spheroidal pollen and the broadly clavate stigma with a conspicuous stylar canal are, however, quite distinct (Fig. 2). Interestingly, no evidence of lamina abscission was found in wild populations or in cultivated specimens.

Within Streptocarpus, pollen morphology has been useful in delimiting various groups (Weigend \& Edwards, 1996). Most of the rosulate species from South Africa form a monophyletic group with notable vegetative, floral and palynological uniformity (Weigend \& Edwards, 1994a,b). The pollen in this group is always prolate, 22 $24 \times 11-13 \mu \mathrm{m}$, and irregularly perforate with widely spaced scabrae (Weigend \& Edwards, 1996). The colpi of this group are consistently narrow and smooth, rarely with finely verrucose poles. This pattern differs from the grains of $S$. lilliputana, which are spheroidal, $12-15 \mu \mathrm{m}$ in diameter, non-perforate, and densely scabrate with coarsely verrucose colpi. The grains also show consistent wrinkling of the apocolpium, a character not recorded elsewhere in the genus (Fig. 3).

A comparison of the DNA sequences of the internal transcribed spacer regions (ITS1 and ITS2) and the 5.8S rRNA gene of nuclear ribosomal DNA genes 

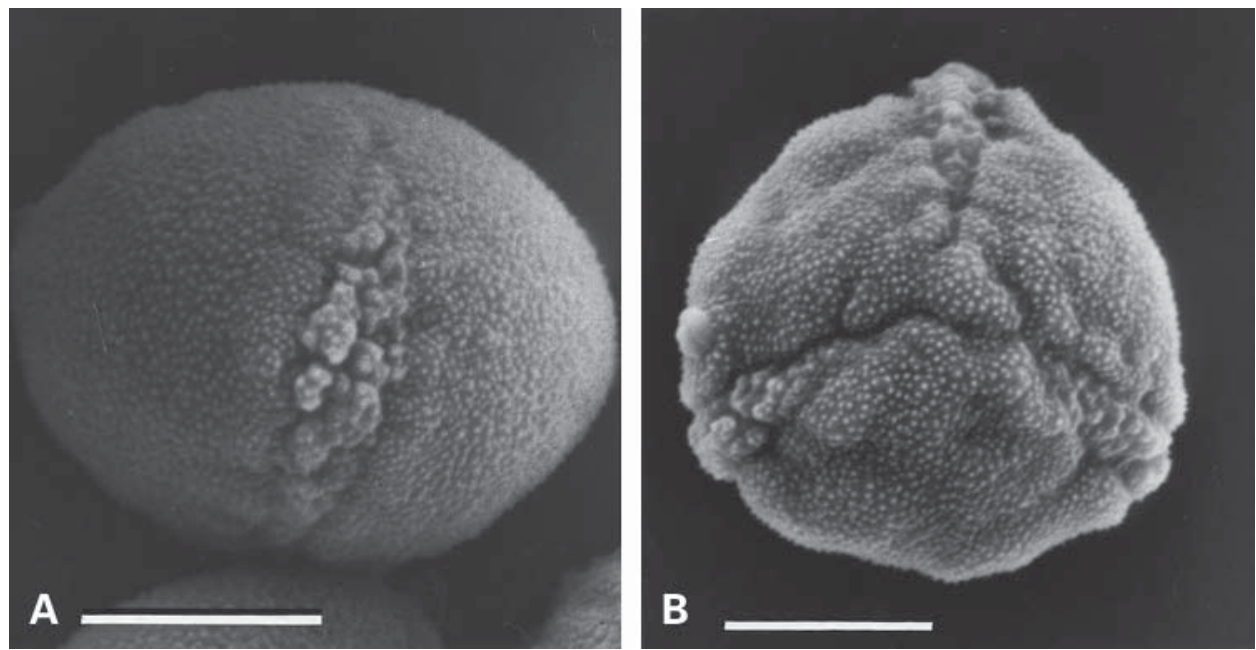

FIG. 3. Pollen grain of Streptocarpus lilliputana (Bellstedt 145) under scanning electron microscopy. A, equatorial view (scale bar $=5 \mu \mathrm{m})$; $\mathrm{B}$, polar view $($ scale bar $=5 \mu \mathrm{m})$.

(determined as described by Möller \& Cronk, 1997) reveals high sequence congruence, with some differences from those of other species of Streptocarpus occurring on the Pondoland coast (see above) and species in the $S$. rexii aggregate. Maximum parsimony analysis of these data showed that $S$. lilliputana appeared in an unresolved basal position in a clade with $72 \%$ bootstrap support formed by a group of 15 southerly species (including $S$. rexii, $S$. primulifolius, $S$. johannis, S. modestus, $S$. meyeri and $S$. baudertii; Bellstedt, unpublished), which supports its species status.

The first population recorded of $S$. lilliputana consisted of about 15 plants in riverine forest in the lower reaches of the Lupatana River Gorge. This small fragment of afromontane forest is harvested for firewood, and this population is highly endangered. The establishment of dwellings in the immediate vicinity of the gorge and the removal of shading trees is of great concern. A subsequent investigation in the very narrow upper Lupatana Gorge revealed a larger population on inaccessible mossy vertical rock faces. The species was also recorded in the upper reaches of the Mkozi River, about $15 \mathrm{~km}$ to the southwest of the Lupatana River, in similar habitats. Further investigation of the highly inaccessible river gorges between these two locations may reveal further populations. So far only an extremely narrow distribution in the river gorges of the northeastern Ntsubane Plateau and the Lupatana River Gorge has been documented. It is important that careful inventories are made of the isolated patches of forest in this area because they appear to represent refugia within which neoendemic herbaceous taxa occur.

\section{ACKNOWLEDGEMENTS}

Elize Cloete, Ben Dekker, Liesl van der Walt and Ernst van Jaarsveld are thanked for their assistance in the field. Mike Lambert is thanked for providing the Latin 
diagnosis. Liesl van der Walt is also thanked for suggesting the name. The Electron Microscope Centre at Natal University is thanked for use of their facility. Professor Olive Hilliard and Mr Bill Burtt are thanked for critical reading of an earlier draft of this manuscript. This research was funded by the National Research Foundation of South Africa, the Natal University Research Fund and the University of Stellenbosch.

\section{REFERENCES}

Hilliard, O. M. \& Burtt, B. L. (1971). Streptocarpus: An African Plant Study. Pietermaritzburg: Natal University Press.

Matolweni, L. O., Balkwill, K. \& Mclellan, T. (2000). Genetic diversity and gene flow in the morphologically variable, rare endemics Begonia dregei and Begonia homonyma (Begoniaceae). Amer. J. Bot. 87: 431-439.

Möller, M. \& CRONK, Q. (1997). Origin and relationships of Saintpaulia (Gesneriaceae) based on ribosomal DNA internal transcribed spacer (ITS) sequences. Amer. J. Bot. 84: 956-965.

VAN WYK, A. E. (1990). Floristics of the Natal/Pondoland Sandstone forests. In: Palaeoecology of Africa and the Surrounding Islands, vol. 21, pp. 243-257. Rotterdam: A.A. Balkema.

Van Wy , A. E. \& Smith, G. F. (2001). Regions of Floristic Endemism in Southern Africa. Pretoria: Umdaus Press.

Weigend, M. \& Edwards, T. J. (1994a). Notes on Streptocarpus primulifolius (Gesneriaceae). S. Afr. J. Bot. 60(3): 168-169.

Weigend, M. \& Edwards, T. J. (1994b). Notes on Streptocarpus cyaneus and $S$. parviflorus. Sendtnera 2: 365-376.

Weigend, M. \& Edwards, T. J. (1996). The palynology of Streptocarpus and other African and Malagasy Gesneriaceae and its systematical implications. Bot. Jahrb. Syst. 118: 59-80.

An invited contribution to the Festschrift for B.L. Burtt's ninetieth birthday 